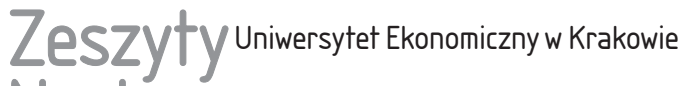 Naukowe
}

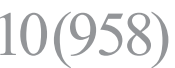

ISSN 1898-6447

Zesz. Nauk. UEK, 2016; 10 (958): 5-20

DOI: 10.15678/ZNUEK.2016.0958.1001

\section{Is Financial Reporting in the SME Sector Moving towards Transparency? The Evidence from Poland}

\begin{abstract}
In the context of the transparency of accounting information, the paper presents new approaches to accounting and financial reporting of enterprises from the SME sector. Therefore, accounting cannot be analysed without the context of particular conditions of individual countries, their social, economic and cultural development. One country - Poland - was selected for the study. The paper is not an in-depth analysis of IFRS for SMEs, Directive 2013/34/ EU and the amended Polish Accounting Act, but only applies to issues directly associated with financial statement transparency. This is a discussion paper that does not unequivocally resolve the matter under consideration, but presents possible approaches and encourages the undertaking of further research.
\end{abstract}

Keywords: IFRS for SMEs, Directive 2013/34/EU, transparency of the financial statement, simplifications in accounting.

JEL Classification: M41.

Kinga Bauer, Department of Accountancy, Cracow University of Economics, Rakowicka 27, 31-510 Kraków, Poland, e-mail: kinga.bauer@uek.krakow.pl 


\section{Introduction}

The significance of enterprises of the SME sector for the economies of particular countries, regions and the world is discussed in numerous scientific studies, analyses and reports. The multifaceted interest in this sector stems from the fact that these companies are essential for both developed and developing economies (Radas \& Božić 2009). The development of the SME sector is supported by the European Union, because it is important for the entire economy, taking into account individual, local markets (Czegledi, Fonger \& Reich 2015). More and more often SMEs are treated not only as enterprises with a large share in local markets, but also as ones leading a policy of expansion on international markets as well as investing in development in order to gain a competitive advantage (Hsuehchang 2013). From this perspective, it is important for companies from the SME sector to provide credible, reliable information about their financial condition to both contractors and external investors. Their participation in global markets increases the need to guarantee comparability of their financial data, even on an international scale. In contrast, this group also includes entities which, in accordance with the applicable national regulations, do not have to follow rules of accounting, but settle everything with the tax office based on simplified rules. In Poland, the income limit requiring bookkeeping is 1.2 million euros (see Bauer 2013). For companies that do not have that requirement, the basic criterion of choice in the field of recording economic activity is the form of income taxation. It should be pointed out that companies not subject to mandatory bookkeeping have limited information about their financial condition and the condition of their assets (see Bauer 2010). However, in this paper attention will be focused only on those companies that prepare financial statements in accordance with accounting principles.

The purpose of the paper is to analyse the changes in the legal regulations relating to financial reporting of enterprises from the SME sector in the context of preserving the transparency of financial information for stakeholders. The characteristics of stakeholders as those affecting the perception of transparency of financial statements will be discussed. The analysis is to determine whether the current changes in the reporting obligations of SMEs are beneficial from the users' perspective. The research method comprised an analysis of international standards, EU directives and the Polish Accounting Act in relation to SMEs and straightforward reasoning.

Because Poland has been selected as the case for study on the transparency of financial reports of enterprises from the SME sector, the focus of this paper is on legal regulations of:

- IFRS for SMEs as an option that could be introduced by various European Union countries, including Poland. The European Union has left the choice of 
whether to implement IFRS for SMEs up to the individual member states. Poland has decided not to implement it, even though its has many supporters;

- Directive 2013/34/EU, which had a significant impact on the provisions contained in The Polish Accounting Act, the main piece of legislation regulating issues related to financial reporting of enterprises in Poland, including enterprises from the SME sector. Despite the existence of national legislation, Poland must, as an EU member state, adapt it to EU regulations, including Directive 2013/34/EU.

\section{Transparency of Financial Statements as an Essential Feature for the Stakeholders in the SME Sector: Evidence from Poland}

The specificity of the SME sector forces a different approach to the users of SME financial statements. Companies from this sector have fewer stakeholders than do large companies, though it is similarly diverse. Owners and managers are the primary internal stakeholders (in the SME sector these positions are often held by the same people). The dominant external stakeholders are the tax and social security offices. Their main concern is whether a company has properly calculated and paid the tax and insurance it owes. In the economic activities of SMEs, there are also situations in which a company uses financial statements when trying to get a bank loan, applying for EU funds, or when forced to file for bankruptcy in court. In a general sense, the external stakeholder also include society and state (see Bauer 2010). Practice shows that the public expresses little interest in financial statements of entities from the SME sector. However, for the needs of government institutions, financial statements are used to make reports for such companies.

The main difference may lie not only in the number of interested parties, but in the objectives of internal stakeholders. This leads to different, often more basic, information needs in contrast to large companies, which employ specialised financial and accounting staff and benefit largely from external financing. Undoubtedly, globalisation has led SMEs to assume a more active role in the exchange of goods and services in the world markets. However, according to research conducted in Poland, a lack of knowledge, managerial skills and specialised personnel in SMEs remains a clear problem. A widespread lack of financial analysis is one of the causes of major crisis and bankruptcy in the sector (see Bauer 2011, p. 49)1. Martyniuk and Gierusz (2008) and Woźniak (2006) both pointed to an inability among SMEs to use specialised personnel. Research also shows that managerial staff at SMEs lack education (Polaczek 2010) and that a low proportion of staff is university educated (Martyniuk \& Gierusz 2008).

${ }^{1}$ In Poland, the vast majority of bankrupt companies are small and medium-sized. In 2014,86\% of companies that went bankrupt had a turnover of less than 50 mln PLN (Coface Report 2016). 
A company's inability to employ its own staff in accounting departments means accounting services are often outsourced (Świetla 2013). While this is undoubtedly made easier by the progressive virtualisation of information (Bauer \& Baran 2015), the recording of accounting data with the help of external accounting offices despite it being done electronically - eliminates the possibility of gaining daily insight into accounting processes (Świetla 2014). Despite having limited access to accounting information, SMEs generally choose this method of recording operations. This means that reducing costs is of greater importance than having constant access to accounting information. On the other hand, according to a study conducted in 2011-2013 by Juźwicka and Zakrzewska-Bielawska (2014, p. 34-35), while most of the entities indicate that a lack of accounting knowledge is the reason they outsource accounting services, they point out that accounting represents an opportunity to manage costs, liquidity, and even to develop systems of bankruptcy risk assessment (2015, p. 224).

In this context, the basic problem is figuring out the information needs of the SME sector, as well as the specific usefulness of accounting information. Financial statements have traditionally provided information to a wide range of users about the entity's financial condition. According to the current version of IFRS, capital providers are the group which is most interested in the information contained in financial statements. However, accounting practitioners draw attention to the excessive difficulties accounting poses, especially for smaller businesses. Current solutions are often viewed as excessive, overly time-consuming and to generate excessive costs (Cebrowska 2013). As Mensah, Nguyen, and Prattipati wrote (2006, p. 47), „Transparency has emerged as one of the most widely used characterisations of desirable financial reporting in recent years". A financial statement is transparent if it has a proper positioning system, an appropriate grouping of entries according to their economic content, and a format which facilitates the understanding of the entity's financial condition (Krzywda 2003). The definitions of transparency (in this case, corporate transparency) highlight aspects such as the widespread availability of relevant, reliable information about periodic performance, financial position, investment opportunities, governance, value, and risk (Bushman \& Smith 2003). Transparency is also commonly defined in terms of the ability of the user to attain economic content from financial reporting (Mensah, Nguyen \& Prattipati 2006). The central question then becomes whether extensive financial reports can be transparent, and thus useful to stakeholders of companies from the SME sector. In the context of the foregoing, a more appropriate measure to take towards transparency is to make the extensiveness of financial statements contingent on the size of the entity, and to standardise and facilitate the comparability and accessibility of SMEs' financial statements. These activities 
are conducive to changes in legal regulations regarding the financial reporting of entities in the SME sector.

\section{Global Efforts in the Scope of the Transparency of Financial Reporting of Enterprises from the SME Sector}

\subsection{IFRS for SME: Operations for Comparability on a Global Scale}

Every country has its own accounting system. In the era of globalisation, differences between their accounting systems make it difficult to communicate in business. However, the creation of a global accounting system based on a single set of concepts, principles, rules and procedures would be virtually impossible (Krasodomska 2010). Attempts are nonetheless being made to increase the comparability of information that comes from the accounting of firms from different countries. The implementation of the International Financial Revision Standards (IFRS) is a sign of these attempts, and is likewise occurring in the SME sector. According to the IASB, over 80 jurisdictions have either adopted the IFRS for SMEs (Międzynarodowy Standard... 2009) or stated a plan to do so within the next few years. This standard was already in use at businesses as small as just a few people.

The positive aspect of IFRS for SMEs is that it is more straightforward than full IFRS. The language used is simpler and there is less of it by volume to read. The elements of financial statements have also been simplified (for example, the statement of changes in equity may be left out) and the amount of information that must be presented has been reduced. The fact that changes in standards are made not more than once every three years also facilitates their use (Kuzior 2011).

The application of IFRS for SMEs was controversial from the outset, so analysis of the opportunities and constraints associated with its implementation is ongoing. One indication of the study being conducted comes from a survey, distributed in 2009 by the General Director or Internal Market and Services of the European Commission to European companies which prepare financial statements, statement users and regulators, organisations which set standards and others. It asked for their views on the advantages and disadvantages of this standard in terms of its possible use in the countries of the European Union. The questions covered such aspects as the scale on which it is possible to apply the IFRS for SMEs, the cost of their implementation, impact in terms of comparability, and legal issues related to the principles of their implementation.

While the results are not conclusive, the answers show considerable objections and doubts, especially in terms of the possibility of providing statement compara- 
bility in the event that IFRS is implemented for SMEs. The results of the survey indicated respondents' concerns about the excessive complexity of IFRS for SMEs. The vast majority of respondents feared the high cost of adapting existing internal procedures, training personnel and advisory services. These costs are perceived to be high not only during the implementation of the standards, but also for subsequent updates, and even the preparation and audit of financial statements (Szewc 2011). These concerns are different than those surrounding the objectives for which the IFRS for SMEs were created. One reason IFRS was created was to balance benefits and costs - i.e. to provide a report genuinely presenting the condition of a company, but at a lower cost than that associated with the use of complete IFRS (Kuzior 2011).

An assessment carried out by European accountants and auditors also did not give an explicit opinion supporting the introduction of IFRS for SMEs. As a result of the study, the following has been concluded: although harmonisation of accounting standards is positive, whether IFRS would bring about greater international comparability of financial statements is a matter for dispute. It should, however, help improve the quality of financial statements of the companies in the sector. One of the most serious allegations against IFRS for SMEs is the fact that micro entities are not excluded from reporting obligations (Kędzior 2011). The results from an analysis conducted by Quagli (2010) concerning the answers to a "Questionnaire on the public consultation of the IFRS for SMEs" showed significant differences in the approach to these standards. Users provided a more positive assessment than did preparers, who came down squarely against the IFRS for SMEs. The study also found that the approach to standards varied by the respondents' country of origin. In German-speaking countries and Latin countries, the standards were given much less credit than in Anglo-Nordic countries.

Empirical research on the implementation of the IFRS for SMEs has been conducted in many countries. The results indicate that they are perceived as problematic or even unnecessary. For example, companies in South Africa do not perceive these standards as reducing the burden of preparaing financial statements, and some aspects seem to be inadequate for this sector (Van Wyk \& Rossouw 2009). Companies from the SME sector in the Czech Republic, which are not obliged to apply IFRS, expressed little interest in preparing financial statements in accordance with the standards (Strouhal et al. 2009).

While it is acknowledged that the implementation of IFRS for SMEs can be beneficial in achieving the principles of a true and fair view as well as greater comparability of financial statements on an international scale, there is a lack of motivation to implement them. This is because there is greater interest in the tax aspect and linking national accounting rules with tax regulations than in the principle of presenting a true and fair view (Strouhal 2012). A similar conclusion 
comes from research carried out in Romania. Difficulties with the possible implementation of IFRS for SMEs, particularly with regard to regulations concerning taxes, were identified (Albu et al. 2010, p. 662). Research carried out by Bohušová and Blašková (2013) on a group of countries that adopted IFRS for SMEs shows that the standards will be taken on in countries where the financial reporting system is on a qualitatively lower level. Countries with a highly developed system of financial reporting will most likely choose not to adopt the standard. The implementation of IFRS for SMEs will lead to additional costs exceeding the benefits in those countries ${ }^{2}$.

The results of studies conducted in Turkey (Kılıç, Uyar \& Ataman 2014), which adopted the standards in 2010 but decided to use them only from 2014, indicate the same problems occurred there as elsewhere: lack of training and high costs. On the other hand, the respondents among accounting professionals see the following advantages: comparability, reliability, transparency and understandability of financial statements and effective financial reporting.

International studies on a group of 128 countries indicate that a much greater tendency to adopt IFRS for SMEs exists among countries which lack capabilities to develop their own local GAAP and those whose SME sector entities were previously required to use full IFRS (Kaya \& Koch 2015). As a result of these studies, serious flaws in the standards have been disclosed and so they were not approved by the European Commission. In view of these challenges, the EU has begun revising existing directives on individual and consolidated financial statements. The crowning achievement of this work was the adoption of the Directive 2013/34/EU (Sawicki 2014).

\subsection{Directive 2013/34/EU: Striving to Reduce Burdens while Maintaining the Transparency of Financial Statements}

It has been observed that current demands are intrusive and fail to strengthen development, internationalisation and competitive advantage. A new accounting directive, i.e. Directive 2013/34/EU (Dyrektywa Parlamentu Europejskiego... 2013) on annual and consolidated financial statements and related reports was issued in 2013. The Directive is the outcome of the European Union's analysis on accounting and financial reporting of enterprises from the SME sector. It was found that current encumbrances are burdensome and inadequate in strengthening growth, internationalisation and competitive advantage. The Directive strives to strike a balance between the need for transparent financial reporting and the costs and benefits of transparency. To do so, it is essential to present financial

${ }^{2}$ Research on the applicability of IFRS for SMEs has also been carried out in Poland. The results will be discussed in further sections. 
information in a correct and transparent manner to all parties that have an interest in a company, while maintaining the minimum requirements that must be respected by all entities operating within the EU (d'Angelo 2015). The Directive gives member states the ability to use a number of simplifications. At the same time, it prohibits demanding the disclosure, in the financial statements of small entities, of information other than that specified in the Directive. As a result, no member state may require small businesses to draw up a statement of changes in equity and in the cash flow statement. The financial statement of a small entity consists of a simplified balance sheet, income statement and notes (Sawicki 2015).

The quest for a more rational distribution of costs for accounting activities lies in line with the Europe 2020 strategy, which - among other things - is to simplify the regulations for small and medium-sized enterprises, which constitute about 99\% of all European businesses. EU regulations in recent years significantly differentiate the requirements for micro and small entities, which are private property, as opposed to public interest entities and all medium and large entities (Žárová 2013). In the context of the specificities of micro and small entities and the information needs of users of financial statements, simplifications are definitely called for. According to the Directive, significant simplifications are intended not only to restrict, but to actually affect the accuracy and transparency of financial statements of the smallest entities.

Preliminary results of studies conducted in different EU member states indicate different opinions in this regard. Clearly positive reactions to changes are indicated in research conducted in Croatia. Mamić Sačer, Dečman, \& Sever suggest that thanks to the Directive, micro entities had been set apart and separate, greatly simplified regulations for financial statements were created for them. They indicate that both theory and practice confirmed the need for additional simplification of accounting regulations for the smallest entities, and the introduced changes may contribute to the development of Croatian micro units (Mamić Sačer, Dečman \& Sever 2015).

Italian researchers indicate that some of the innovations contained in the directive are optional and their use depends on individual EU member states. Compared to Italian law, the proposed changes are sometimes very radical. Since the Directive allows the member states to choose solutions, it is unlikely that all will introduce them to an identical extent. Thus the idea to increase the comparability of financial statements of all enterprises in the EU - one of the ideas guiding the creation of Directive 2013/34 / EU - may be impossible to achieve (Provasi \& Sottoriva 2015).

Research was carried out in Czech Republic to determine and evaluate the impact of transposing the Directive into the Czech Accounting Law. The results indicate that an amendment to the Czech Accounting Act uses almost all options 
for simplifications or exemptions allowed by the EU directive to reduce the administrative burden for micro and small enterprises. The authors expressed concern, however, as to whether the EU directive, which was also intended to reduce the administrative burden on the smallest units, will limit basic accounting principles, including true and fair presentation (Bušovová et al. 2016).

In the light of this review of the literature, I would emphasise that these are preliminary results. That the financial statements prepared in accordance with the principles of Directive 2013/34/EU adapted by national law will be drawn up in the future means that empirical research can be conducted in the following years. Presently, research on the impact of the Directive on the quality of information contained in financial statements is more conceptual. The future will bring real change in this regard.

\section{Changes in the Financial Reporting of the SME Sector in Poland}

\subsection{IFRS for SMEs: Are Polish Businesses Ready for This Standard to Be Introduced?}

Poland is one of the countries in which the adoption of IFRS for SMEs has been considered, and therefore the possibility of its implementation has raised keen interest among theorists and practitioners. As elsewhere, opinions there are divided. As Grabiński, Kędzior and Krasodomska (2014) point out, the standard is also controversial in Poland. On the one hand, it has been recognised as a potentially important step towards the harmonisation of accounting in the sector, which may improve confidence in its accounting. Implementation of the standard will improve the comparability of financial statements and facilitate an increase in capital locally and internationally. On the other hand, it is complicated and the implementation is expensive. The need to pass information by companies in the SME sector to a wide range of users is also questioned. According to Gabrusewicz (2008), the implementation of IFRS for SMEs is justified by the sporadic fair value estimation in this sector, the determination of goodwill, acquisition or merger. Empirical studies have been conducted on various issues related to SMEs applying the standard in Poland.

Research on the usefulness of the standard was carried out under the direction of Kamela-Sowińska. The study involved $16 \mathrm{SME}$ sector companies that prepare simplified financial statements in accordance with the Polish Accounting Act. The respondents - mostly CEOs and chief accountants - decided that IFRS would not facilitate their accounting activities, and the multitude of regulations would have no practical use (Gabrusewicz 2008). 
In November 2009, empirical research was conducted by Gockowska on a group of 117 employees from the accounting departments of enterprises from the SME sector in Poland's Pomorskie region. Most of the surveyed companies (74\%) prepared financial statements, including $48 \%$ in full form, and $26 \%$ in a simplified form. The study pertained only to the expected benefits of implementing the IFRS, which are as follow (Martyniuk-Kwiatkowska 2011):

- increasing the company's reliability,

- creating transparent information for the owners,

- facilitating the transition to full IFRS,

- facilitating economic activities on an international scale,

- the possibility of obtaining cheaper capital.

Of particular note is that of the accounting staff surveyed, only $38 \%$ had heard of IFRS for SMEs, and 3\% had read the English version (Martyniuk-Kwiatkowska 2011). This may be because at the time the staff were interviewed, there was no Polish language version of the standard. At the same time, during the period at which the research was being carried out in Poland, interest in the English version of the standard IFRS for SMEs in global Internet resources was highest over the years 2006-2016 (https://www.google.pl/trends/explore\#q=ifrs\%20for\%20smes, accessed: 30 June 2016).

Lack of knowledge on the IFRS for SMEs among the surveyed accounting staff may indicate a lack of information needs on an international scale by smaller companies in Poland or be the result of other problems, e.g. low professional expertise.

Undeniably, the IFRS standard for SMEs is the result of efforts to harmonise accounting principles in the world. However, the scope of information generated by accounting entities must be adapted to the opportunities arising from the size and characteristics of a particular company and the needs of the information recipients (Tokarski 2011). The problem of implementing the IFRS for SMEs in Poland has not yet been resolved, but there is a visible aversion to such a solution among practitioners (Bauer 2014). The last two years have brought about simplifications in accounting done by the smallest entities in Poland.

\subsection{The Amended Polish Accounting Act: Towards Simplification of Financial Reporting of the Smallest Entities}

Directive 2013/34/EU had a significant impact on the Polish legal regulations regarding financial reporting of the smallest entities. The amendment of regulations is conducive to standardising financial statements drawn up by designated groups of entities. It is important to allow a direct comparison of the information contained in the financial statements of small entities operating in EU countries. 
In practice, solutions for small entities differ slightly from the ones that preceded them, and the simplifications can create a more unreliable representation. The main simplifications concern micro entities (Sawicki 2015, p. 586, 592).

The amendment to the Polish Accounting Act (Ustawa o rachunkowości... 1994) in 2015 - according to the Directive - introduced a simplification for small and, most importantly, micro entities. It is an effort to maximise the simplification of economic reality, in order to reduce the bureaucratic burden for entities (eg. Osikowicz 2015, Kaczmarczyk 2015). As a result, the financial statement of these entities consists of a reduced number of items of the balance sheet, income statement and general information. However, the changes, which are aimed at reducing the costs associated with small business accounting, in practice mainly result in changes in the financial statements, and not in the scope - and the resulting burdens - of accounting. It is therefore doubtful that the changes will actually reduce the costs of accounting (Poniatowska 2015, p. 320).

The scientific community does not lack a critical approach to the changes. According to Poniatowska (2015), the usefulness and usability of financial statements of micro and small entities to both external and internal users is questionable. Kaczmarczyk (2015) draws attention to the fact that among micro entities there are also joint-stock companies, and the circle of information users is wider. The amendment exempts joint-stock companies classified as micro entities from the cash flow statement and statement of changes in equity, and allows them to draw up the remaining parts of the financial statement in a greatly reduced form. According to Jonas (2015), the scope of information (especially for micro entities) is too reduced and could in practice cause problems in getting the acceptance of these report users. The transition by micro units to the variant currently prepared for them will not only complicate the analysis and disturb comparability, but in the early years might also make it more difficult for them to access capital. Jonas postulates a cautious approach to the possibility of using the simplifications and adjusting their selection to the needs of a particular entity.

\section{Conclusions and Further Research}

The 21st century has seen intensive work done on the regulations for accounting entities in the SME sector. Proposed changes address efforts to increase the transparency of information in the financial statements of SMEs entities.

Measures to improve the comparability of financial statements of SMEs led to the IFRS for SMEs. Opinions on this standard vary greatly. The decision of the European Commission points out, however, a negative attitude to this standard. The Commission ultimately struck it down because it does not take into account 
the specific characteristics of these entities and the relation of costs to benefits of its implementation raises doubts (Szewc 2011).

Ultimately, Directive 2013/34/EU was adopted; its main objective is to reduce the burden of carrying out accounting and simplify the financial statements of the smallest entities. The directive is not, however, isolated from issues related to the transparency of financial statements, but is indeed focused on unification within the European Union.

Changes in the Polish Accounting Act which allow for far-reaching simplifications were at last introduced in Directive 2013/34/EU. As yet, no research results have been published on whether stakeholders' expectations in relation to the informative value of the financial statements of micro and small entities have been met. If taken as a criterion of measurement, the view that transparency in this case is associated with the ability of the user to acquire economic content from financial reporting then research in this direction is particularly valuable to evaluating changes. Earlier empirical research conducted in Poland on the one hand revealed problems with the use of information coming from accounting of the smallest entities and voluntary resignation from access to current accounting information (outsourcing accounting services) in exchange for a lower cost of conducting economic activities. On the other hand, other studies point to the use of information coming from accounting in building an early bankruptcy-warning model (e.g. Zakrzewska-Bielawska \& Juźwicka 2015). Thus, doubts about the possibility to prepare financial analyses based on the current version of financial statements are justified.

This paper is a discussion and has not sought to determine whether the financial statements of SMEs are heading towards transparency. The answer to this question depends on the specific characteristics of individual entities, and empirical research can be carried out only after financial statements have been drawn and later made available for the years when the regulations have been in practice. The same position has been proved by research conducted in other EU member states, which also do not have financial statements prepared after changes in accordance with Directive 2013/34/EU have been introduced into national legislation concerning accounting.

\section{Bibliography}

Albu C. N., Albu N., Fekete S., Cuzdriorean-Vladu D. D. (2010), IFRS for SMEs in Europe - Lessons for a Possible Implementation in Romania (in:) "Proceedings of the 5th WSEAS International Conference on Economy and Management Transformation", vol. 2. 
Bauer K. (2010), Przesłanki i warunki wykorzystania rachunkowości i analizy finansowej w biznesplanie małego przedsiębiorcy, "Przedsiębiorczość - Edukacja", no 6.

Bauer K. (2011), Management of Enterprises from the SME Sector and Their Bankruptcy Risk (in:) Management under Conditions of Risk and Uncertainty, ed. B. Domańska-Szaruga, W. Wereda, EMKA, Warszawa.

Bauer K. (2013), Rachunkowość a potrzeby informacyjne matego przedsiębiorstwa, "Zeszyty Naukowe US. Finanse, Rynki Finansowe, Ubezpieczenia", no 58.

Bauer K. (2014), Małe i średnie przedsiębiorstwa wobec Międzynarodowego Standardu Sprawozdawczości Finansowej (in:) Poszukiwanie przewagi konkurencyjnej: wybrane uwarunkowania, ed. M. Baran, Wydawnictwo Uniwersytetu Jagiellońskiego, Kraków.

Bauer K., Baran M. (2015), Virtualization of Information as the Direction of Development of Accounting Support Systems. Empirical Evidence from Poland, "International Journal of Accounting and Economics Studies", no 3(2), https://doi.org/10.14419/ijaes. v3i2.5194.

Bohušová H., Blašková V. (2013), In What Ways Are Countries Which Have Already Adopted IFRS for SMEs Different, "Acta Universitatis Agriculturae et Silviculturae Mendelianae Brunensis", no 60(2), https://doi.org/10.11118/actaun201260020037.

Bushman R. M., Smith A. J. (2003), Transparency, Financial Accounting Information, and Corporate Governance, "Financial Accounting Information, and Corporate Governance. Economic Policy Review", no 9(1).

Bušovová A., Dřínovská E., Gláserová J., Otavová M. (2016), Will the Czech Accounting Entities Benefit from the Directive 2013/34/EU?, "Procedia - Social and Behavioral Sciences", no 220, https://doi.org/10.1016/j.sbspro.2016.05.471.

Cebrowska T. (2013), Kto i czego potrzebuje od rachunkowości małych i średnich przedsiębiorstw, "Rachunkowość", no 6/2013.

Coface Report (2016), http://www.coface.pl/Aktualnosci-i-Media/Biuro-prasowe/Cofaceopublikowal-raport-nt.-bankructw-w-Polsce-w-2014-r, accessed: 1 February 2016.

Czegledi C. S., Fonger J., Reich M. (2015), EU Policies to Support Small and Medium Sized Enterprises and the German Mittelstand, "Managerial Challenges of the Contemporary Society. Proceedings", no 8(1).

D'Angelo P. (2015), Directive 2013/34/EU on Annual and Consolidated Financial Statements and Related Reports, "Newsletter for The European Union", http://www. newslettereuropean.eu/directive-201334eu-annual-consolidated-financial-statementsrelated-reports/, accessed: 22 January 2016.

Dyrektywa Parlamentu Europejskiego i Rady z dnia 26 czerwca 2013 r. nr 2013/34/UE w sprawie rocznych sprawozdań finansowych, skonsolidowanych sprawozdań finansowych i powiązanych sprawozdań niektórych rodzajów jednostek, zmieniająca dyrektywy Rady 78/660/EWG i 83/349/EWG, Dz.Urz. UE z 29.06.2013 L182, http://www. mf.gov.pl/c/document_library/get_file?uuid=9804da80-d188-4660-8f6f-989ba868de76\&groupId=764034, accessed: 30 June 2016.

Gabrusewicz T. (2008), Próba syntetycznej prezentacji wyników testu przydatności Międzynarodowego Standardu Sprawozdawczości Finansowej dla Małych i Średnich Przedsiębiorstw, "Zeszyty Teoretyczne Rachunkowości”, no 47.

Grabinski K., Kedzior M., Krasodomska J. (2014), The Polish Accounting System and IFRS Implementation Process in the View of Empirical Research, "Accounting and Management Information Systems", no 13(2). 
Hsuehchang T. (2013), The Effects of Intangible Assets (IA) on the Loan Interest Rates for Small- and Medium-Sized Enterprises (SMEs) in Taiwan, "Journal of Modern Accounting and Auditing", July, vol. 9, no 7.

Jonas K. (2015), Sprawozdania finansowe jednostek mikro i jednostek małych jako wyraz dqżenia do uproszczenia sprawozdawczości finansowej (in:) Sprawozdawczość i rewizja finansowa: uwarunkowania ekonomiczne, społeczne i regulacyjne, ed. B. Micherda, Wydawnictwo Uniwersytetu Ekonomicznego w Krakowie, Kraków.

Juźwicka A., Zakrzewska-Bielawska A. (2014), Kompetencje pracowników a outsourcing służb finansowo-księgowych $w$ małych przedsiębiorstwach, "Zeszyty Naukowe Politechniki Łódzkiej. Organizacja i Zarządzanie", z. 57.

Kaczmarczyk A. (2015), Sprawozdawczość finansowa jednostek mikro w aspekcie zasady wiernego i rzetelnego obrazu, "Prace Naukowe Uniwersytetu Ekonomicznego we Wrocławiu", no 388, https://doi.org/10.15611/pn.2015.388.25.

Kaya D., Koch M. (2015), Countries' Adoption of the International Financial Reporting Standard for Small and Medium-sized Entities (IFRS for SMEs) - Early Empirical Evidence, "Accounting and Business Research", no 45(1), https://doi.org/10.1080/0001 4788.2014.969188.

Kędzior M. (2011), Ocena MSSF dla MŚP przez europejskich księgowych i audytorów, "Rachunkowość", nr 9.

Kılıç M., Uyar A., Ataman B. (2014), Preparedness for and Perception of IFRS for SMEs: Evidence from Turkey, "Accounting \& Management Information Systems/Contabilitate si Informatica de Gestiune", no 13(3).

Krasodomska J. (2010), Anglosaski i kontynentalny model rachunkowości na przykładzie wybranych krajów, “Zeszyty Teoretyczne Rachunkowości”, no 55 (111), Stowarzyszenie Księgowych w Polsce, Rada Naukowa, Warszawa.

Krzywda D. (2003), Sprawozdanie finansowe jako produkt rachunkowości jednostki gospodarczej, "Folia Oeconomica Bochniensia: Zeszyty Naukowe", no 1.

Kuzior A. (2011), Podstawowe założenia MSSF dla małych i średnich przedsiębiorstw, "Zeszyty Naukowe Uniwersytetu Szczecińskiego. Finanse. Rynki finansowe. Ubezpieczenia", no 32.

Mamić Sačer I., Dečman N., Sever I. (2015), The Influence of Accounting Regulation Simplification on the Financial Reporting of Micro Entities - the Case of Croatia, "Economic Research - Ekonomska Istraživanja", no 28(1), https://doi.org/10.1080/133 1677x.2015.1084888.

Martyniuk T., Gierusz B. (2008), Czynniki determinujace zdolność finansowa małych przedsiębiorstw, "Zeszyty Naukowe Uniwersytetu Szczecińskiego. Finanse. Rynki finansowe. Ubezpieczenia”, no 13.

Martyniuk-Kwiatkowska O. (2011), Przydatność międzynarodowej regulacji sprawozdawczości finansowej dla małych i średnich przedsiębiorstw (in:) Kluczowe problemy teorii i praktyki rachunkowości, t. 2, Prace i Materiały Wydziału Zarządzania Uniwersytetu Gdańskiego, Sopot.

Mensah M. O., Nguyen H., Prattipati S. (2006), Transparency in Financial Statements: A Conceptual Framework from a User Perspective, "Journal of American Academy of Business", no 9(1).

Międzynarodowy Standard Sprawozdawczości Finansowej (MSSF) dla małych i średnich przedsiębiorstw (MSSF dla MŚP) (2009), Rada Międzynarodowych Standardów Rachunkowości (IASB), http://eifrs.ifrs.org/eifrs/sme/pl/PLSMEs.pdf. 
Osikowicz M. (2015), Rachunkowość jednostek mikro według ustawy o rachunkowości, "Prace Naukowe Uniwersytetu Ekonomicznego we Wrocławiu", no 388, https://doi. org/10.15611/pn.2015.388.16.

Polaczek R. (2010), O potrzebie wyceny małego przedsiębiorstwa, "Zeszyty Naukowe Uniwersytetu Szczecińskiego. Finanse. Rynki finansowe. Ubezpieczenia”, no 25.

Polak W. (2013), Konkurencyjność małych i średnich przedsiębiorstw - aktywność inwestycyjna i bariery rozwoju, "Zeszyty Naukowe Uniwersytetu Szczecińskiego. Finanse. Rynki finansowe. Ubezpieczenia”, no 59.

Poniatowska L. (2015), Zmiany w sprawozdawczości finansowej $w$ regulacjach ustawy o rachunkowości, "Prace Naukowe Uniwersytetu Ekonomicznego we Wrocławiu", no 388.

Provasi R., Sottoriva C. (2015), Preliminary Considerations about the Transposition of Directive 2013/34/EU into Italian Accounting System, "Journal of Modern Accounting and Auditing", no 11(6), https://doi.org/10.17265/1548-6583/2015.06.002.

Quagli A. (2010), How Is the IFRS for SMEs Accepted in the European Context? An Analysis of the Homogeneity among European Countries, Users and Preparers in the European Commission Questionnaire, "Advances in Accounting Incorporating Advances in International Accounting", vol. 28-1, http://ssrn.com/abstract=1638884, accessed: 30 June 2016.

Radas S., Božić L. (2009), The Antecedents of SME Innovativeness in an Emerging Transition Economy, “Technovation”, no 29(6), https://doi.org/10.1016/j.technovation.2008.12.002.

Sawicki K. (2014), Podstawowe kierunki zmian w sprawozdaniach finansowych mikroprzedsiębiorstw wedtug nowej dyrektywy Unii Europejskiej, "Zeszyty Naukowe Uniwersytetu Szczecińskiego. Finanse. Rynki finansowe. Ubezpieczenia”, no 69, Rachunkowość i sprawozdawczość finansowa.

Sawicki K. (2015), Podstawowe kierunki zmian w sprawozdaniach finansowych małych jednostek, "Zeszyty Naukowe Uniwersytetu Szczecińskiego. Finanse. Rynki finansowe. Ubezpieczenia", no 77, Rachunkowość w zarzadzaniu jednostkami gospodarczymi.

Strouhal J. (2012), Testing Accounting Harmonization upon the Globalization of Financial Reporting Systems, "Recent Researches in Engineering Education and Software Engineering", http://www.wseas.us/elibrary/conferences/2012/CambridgeUK/SEPED/ SEPED-27.pdf, accessed: 6 January 2014.

Strouhal J., Müllerová L., Cardová Z., Paseková M. (2009), National and International Financial Reporting Rules: Testing the Compatibility of Czech Reporting from the SMEs Perspective, "WSEAS Transactions on Business and Economics", no 6(12).

Świetla K. (2013), Ewolucja rozwiqzań rachunkowości jako determinanta rozwoju rynku specjalistycznych usług finansowych, "Zeszyty Naukowe Uniwersytetu Ekonomicznego w Krakowie", nr 901.

Świetla K. (2014), Outsourcing usług księgowych w świetle oczekiwań biur rachunkowych i ich klientów, Zeszyty Naukowe Uniwersytetu Ekonomicznego w Krakowie, Seria specjalna: Monografie, $\mathrm{nr} 231$.

Szewc M. (2011), Celowość stosowania MSSF dla MŚP. Wyniki ankiety europejskiej, "Rachunkowość", no 3.

Tokarski M. (2011), Międzynarodowe standardy sprawozdawczości finansowej w procesie harmonizacji i standaryzacji rachunkowości w Polsce, "Przedsiębiorczość-Edukacja", no 7. 
Ustawa z dnia 29 września 1994 r. o rachunkowości, Dz.U. 1994, nr 121, poz. 591, z późn. zm. Van Wyk H. A., Rossouw J. (2009), IFRS for SMEs in South Africa: A Giant Leap for Accounting, But Too Big for Smaller Entities in General, "Meditari Accountancy Research", no 17(1), https://doi.org/10.1108/10222529200900007.

Woźniak M. G. (2006), Rozwój sektora małych i średnich przedsiębiorstw w Polsce a wzrost gospodarczy, Wydawnictwo Akademii Ekonomicznej w Krakowie, Kraków.

Zakrzewska-Bielawska A., Juźwicka A. (2015), Rola organizacji rachunkowości w profilaktyce antykryzysowej w małych przedsiębiorstwach, "Marketing i Rynek", no 5 (CD).

Žárová M. (2013), Could New Accounting Directive Improve European Financial Reporting?, "European Financial and Accounting Journal", no 2013(2), https://doi. org/10.18267/j.efaj.97.

\section{Czy sprawozdania finansowe przedsiębiorstw z sektora MŚP zmierzają w stronę przejrzystości? Polskie doświadczenia}

(Abstract)

W artykule przedstawiono nowe podejścia do rachunkowości i sprawozdawczości finansowej przedsiębiorstw z sektora MŚP w kontekście przejrzystości informacji księgowej. W związku z tym, iż nie można rozpatrywać rachunkowości w oderwaniu od specyficznych uwarunkowań poszczególnych krajów, ich rozwoju społecznego, ekonomicznego i kulturowego, do badań wybrano jeden kraj: Polskę. Artykuł nie stanowi dogłębnej analizy MSSF dla MŚP, Dyrektywy 2013/34/EU i znowelizowanej Ustawy o rachunkowości, lecz jedynie odnosi się do kwestii bezpośrednio wiążących się z przejrzystością sprawozdań finansowych. Jest to artykuł dyskusyjny, który nie rozstrzyga jednoznacznie badanego tematu, lecz przedstawia możliwe podejścia i zachęca do dalszych badań w tym obszarze.

Słowa kluczowe: MSSF dla MŚP, Dyrektywa 2013/34/UE, przejrzystość sprawozdań finansowych, uproszczenia w rachunkowości. 